\title{
EDITORIAL
}

\section{Back to the Sources of Value Theory and Practical Philosophy}

The international philosophical community will certainly remember 2016 as the Year of Aristotle. The reason for this is the impressive number of conferences, colloquia and lectures organized worldwide on the occasion of the $2400^{\text {th }}$ anniversary of the birth of the ancient philosopher, and in particular the International Multiple Congress "Aristotle Today", which took place in Athens, Heidelberg, Padua, Paris, Helsinki, Lisbon, Notre Dame (Indiana), Moscow, Córdoba, Leuven, and Sofia. However, if we have chosen to dedicate the second issue of Labyrinth 2016 to Aristotle, it is not simply in order to take part in this splendid anniversary celebration, but also to recall that "in the history of value theory (...) Aristotle should always be mentioned in the first place not only chronologically, but also in view of his importance", as once stated Oskar Kraus. In this context, the main objective of this issue is to offer some new readings of Aristotle's axiological ideas and practical philosophy in view of their historical impact and persisting importance. Thus, it is divided in two parts.

The articles included in the first part discuss the origins and the foundations of Aristotelian value theory and practical philosophy. Reinterpreting the meaning of certain fundamental anthropological, ethical and political concepts of Aristotelian philosophy, such as orexis, pathe, phronèsis, prohairesis, boulēsis, bouleusis, a/o, the authors show their importance for the understanding of human being and human action. As a subject of reason, emotions, aspirations, will, and desires, and having a specific character and individuality, the human being is moved in his/her actions by different motives and instances. Markus Riedenauer shows how emotions function as primary evaluators of situations, and form the basis for virtue ethics by calling human beings to realize the call to morally good and fulfilling action. In this sense, as stated by Audrey L. Anton, "since the vicious person fails to know the good, she neither acts in accordance with it voluntarily nor does she feel appropriately towards the good." Thus, it is important to elucidate the connection between the voluntary and the character as a person's set of fixed dispositions to feel and act in certain ways. Anton's analysis reveals in particular the role of interplay between the internal (character) and external (praise and blame) aspects for steering moral improvement, i.e., a good voluntary behavior. For his part, Wei Liu argues, that "decision" (prohairesis), which includes desiderative and deliberative components, provides the moving cause of rational action, and that it better reveals the person's character than does the action itself. With reference to previous publications and debates, Olav Eikeland offers a detailed reexamination of the relation between "reason", "knowledge", and virtue, in setting the goal for ethical deliberation. 
The articles in the second part of the issue aim to show the historical impact of Aristotelian ethics and theory of action, and especially the diversity of their receptions. In particular, the authors show how problems in modern and contemporary ethical theories (modern virtue ethics, moral individualism, utilitarianism, recursive ethics etc.) can be resolved by using Aristotle's conceptual framework. Thus, Martin Huth investigates the Aristotelian sources of the current critique of moral individualism presented by Cora Diamond, Alice Crary, Paul Ricoeur, Klaus Held, Bernhard Waldenfels, a/o, and analyzes the way they use certain key Aristotelian concepts: (a) "ethos" as the lived moral sense, ground and horizon of moral decision-making and ethical reflection; (b) "hexis" as the morally relevant habituation of perceiving and acting; (c) "phronèsis" as practical wisdom, which is considered to be a specific practical know-how as opposed to the scientific knowledge of the episteme; and (d) the definition of the human being as "zoon politikon", who is "by nature" dependent on social relations, including the development of moral skills. Following Elisabeth Anscombe, Kathi Beier tries to overcome the baselessness of modern virtue ethics by exploring the conceptual connections between virtue and soul in Aristotle's moral philosophy. She claims that the human soul is the principle of virtue since reflections on the soul help us to define the nature of virtue, to understand the different kinds of virtues, and to answer the question as to why human beings need virtues at all. By comparing the virtue conceptions of Christoph Halbig and Max Scheler, Susanne Moser shows that Scheler, similar to Aristotle, understands virtues as a kind of transformers from the negative to the positive, because they fix the right way of dealing with negative emotions and switch over the negative basic mood into a positive, joyful one. In the context of Paul Ricoeur's understandings of human rights and human dignity, Yvanka B. Raynova demonstrates the fruitfulness of the Ricoeurian application of Aristotle's phronèsis in (bio)ethical discussions and cases, where decisions are difficult to take.

We are perfectly aware that no publication can cover even a single subject of Aristotle's gigantic philosophical heritage. Nevertheless, with the present volume we hope to disclose some new aspects of his conceptual framework, which could be helpful for further axiological debates.

Yvanka B. Raynova 